\title{
Soil chemical properties during succession from abandoned cropland to native range
}

\author{
JOHAN F. DORMAAR, SYLVESTER SMOLIAK, AND WALTER D. WILLMS
}

\begin{abstract}
Succession from abandoned cropland to native range provides the opportunity to study soil transformation in progress from a known date. The purpose of this study was to assess soil transformations under abandoned cropland reverting back to native range in the Brown and Black Chernozemic soil zones of southern Alberta, Canada. Total extractable organic acids and phenols were generally greater in abandoned cropland soils than in adjacent native range soils. Ammonium $N$ increased with succession but nitrate $\mathbf{N}$ decreased. Percent identifiable $\mathbf{N}$ of hydrolyzable $\mathbf{N}$ decreased with time of recovery. Aliphatic carboxylic acids increased quantitatively with succession in the Black soils and decreased in the Brown Chernozemic soils. A change in quality of soil organic matter towards a more complex and stable form occurred with time. Regression analyses of the Brown Chernozemic soils abandoned in 1925, 1927, 1950, and 1975 are interpreted to show that response to years of the chemical characteristics studied was essentially linear. In order to form the type of organic matter that occurs in undisturbed Black and Brown Chernozemic soils, recovery of abandoned cropland may take at least 150 years in the former and 75 years in the latter under moderate grazing.
\end{abstract}

Key Words: Alberta, Chernozemic soils, organic matter, nitrogen, phenols, organic acids

Authors are soil scientist, retired range ecologist, and range ecologist, respectively, Agriculture Canada Research Station, Lethbridge. Alberta TIJ 4BI. Contribution 3878903 .

The authors thank Mr. Bob Schuler, Alberta Forestry, Lands and Wildlife, and Dr. B.O.K. Reeves, Department of Archaeology, University of Calgary, for locating some of the fields sampled. Technicians R.R. James and R.K. Lybbert assisted with the laboratory analyses, and J. Elder carried out the GC-MS analyses. We appreciate G.C. Kozub's help with the statistical analyses.

Manuscript accepted 13 November 1989.
Old-field succession is the process whereby cropland is abandoned and allowed to revert to a stable or climax plant community. Large areas of cropland in southern Alberta have been abandoned over the past century during extended periods of low precipitation (Dormaar and Smoliak 1985). This provides an opportunity to examine soil transformations over a given time period.

In a recent study (Dormaar and Smoliak 1985), changes in the vegetation and a number of soil chemical properties during succession from abandoned cropland to native range under semiarid climatic conditions were assessed. However, only 3 fields were studied and all were within the same soil zone. The present study was initiated to investigate soil organic matter and nitrogen recovery processes on abandoned cropland fields located in different soil zones across southern Alberta. As previous studies have indicated that soil nitrogen was greatly affected by old-field successions (Rice 1984, Tilman 1986) and the equilibrium, under which soil organic matter in semiarid soils formed and existed, was fragile (Dormaar et al. 1977), this study seeks to assess the effect of length of time since abandonment on the quality of soil nitrogen and organic matter in a semiarid and a dry subhumid soil zone.

\section{Materials and Methods}

Sites

All areas selected for this study included paired sites of abandoned cropland and adjoining native range. The native range and adjacent abandoned cropland had all been grazed by cattle since abandonment at a moderate rate to provide at least a $50 \%$ carryover of forage. The management history prior to plowing is not known. 
The histories of the abandoned cropland fields are as follows: Manyberries: Site 1925-The field was plowed in 1910, cultivated for 15 years, and abandoned in 1925. Site 1927-The field was plowed in 1917, cultivated for 10 years, and abandoned in 1927. Site 1950-The field was plowed in 1920, cultivated intermittently for 30 years, and abandoned in 1950. Site 1975-The field was plowed in 1975, seeded to introduced grasses that autumn, then abandoned when introduced grasses failed to establish.

Bow Island: Site 1922. The field was plowed in 1912, cultivated for 10 years, and abandoned in 1922.

Fort Macleod: Sites 1884a and 1884b. The fields were plowed in 1883 , cultivated for one year, and abandoned in 1884 .

Stavely: Site 1916. The field was plowed in 1915 , cultivated for one year, and abandoned in 1916.

Soils

The soils of the Manyberries and Bow Island sites are members of the Orthic Brown Subgroup of the Chernozemic Order (Aridic Ustochrept). Soils of the Fort Macleod and Stavcly sites are members of the Rego and Orthic Black Subgroups of the Chernozemic Order, respectively (Entic and Udic Haploborolls). The climates are semiarid and dry subhumid for the Brown and Black Chernozemic soils, respectively. Annual precipitation averages $353,342,434$, and $472 \mathrm{~mm}$ for the 4 sites, respectively (Environment Canada 1982).

\section{Sampling and Preparation}

The Ah $\left(=A_{1}\right)$ soil horizon was sampled during April, 1987. Samples $(2,000 \mathrm{~g})$ were taken from 4 sampling plots randomly located within each treatment pair. The depths of the Manyberries, Bow Island, Fort Macleod, and Stavely Ah horizons were 7, 9, 14, and $17 \mathrm{~cm}$, respectively. The 4 paired sampling plots were located 5 $\mathrm{m}$ from the boundary between abandoned cropland and adjacent native range and $100 \mathrm{~m}$ apart. The samples were hand-sieved through a 2-mm screen, and stored in double polyethylene bags at $4^{\circ} \mathrm{C}$. At the time of sieving, visible roots and other debris were removed from the soil and discarded. Moisture content of the soil for reporting on dry weight bases was determined gravimetrically by drying a small portion of soil overnight at $105^{\circ} \mathrm{C}$.

\section{Analyses}

Mineralizable- $\mathbf{N}$, as an index of biological $\mathbf{N}$ availability, was determined as outlined by Mackay and Carefoot (1981). After the mineralizable- $\mathrm{N}$ analyses, the soils were dried and ground to pass a $0.5-\mathrm{mm}$ sieve. Autoclaveable- $\mathrm{N}$, as an index of chemical $\mathrm{N}$ availability, was determined as described by Keeney (1982). Urease activity was determined on air-dried soils at $\mathrm{pH} 9.0$ according to Tabatabai and Bremner (1972). Total nitrogen $(\mathrm{N})$ was determined as outlined by the Association of Official Agricultural Chemists (1965) and hydrolyzable-N, amino acid-N, and amino sugar-N by methods described by Stevenson (1982). Nitrate $\mathrm{N}\left(\mathrm{NO}_{\overline{3}}-\mathrm{N}\right)$ and ammonium $\mathrm{N}\left(\mathrm{NH}_{4}^{+}-\mathrm{N}\right)$ were determined by steam distillation (Keeney and Nelson 1982). The Folin-Ciocalteau reagent was used to determine the total content of soluble phenolic compounds (Association of Official Agricultural Chemists 1965, Morita 1980).

The method used for studying aliphatic carboxylic acids and phenols was developed from those outlined by Jalal and Read (1983), Pierce Chemical Company (1985), and Vance et al. (1985). The initial step involved extracting the organic compounds from $50 \mathrm{~g}$ of each sample from each sampling plot using $\mathrm{Na}_{4} \mathrm{P}_{2} \mathrm{O}_{7}$ at $\mathrm{pH}$ 10 and acidifying the extract to $\mathrm{pH} 2.5$ with $\mathrm{H}_{2} \mathrm{SO}_{4}$ (Vance et al. 1985). The extracts of the 4 plots/field were combined in order to reduce the number of analyses on the mass spectrometer. The acid-soluble organic substances were analyzed for organic acids and phenolic compounds; the acid-insoluble organic substances were analyzed for aliphatic carboxylic acid.

The acid-soluble organic matter was decanted into a separatory funnel. The dicarboxylic acids and phenols were extracted by liquid-liquid extraction using 3 times $100 \mathrm{ml}$ diethyl ether, and the ether extracts transferred to a $500-\mathrm{ml}$ wide-mouth Erlenmeyer flask. Following the addition of $5 \mathrm{~g}$ of anhydrous $\mathrm{MgSO}_{4}$ for drying the ether extract, the mixture was stirred for $5 \mathrm{~min}$ and filtered (Whatman \#54). The filtrate was reduced to $1 \mathrm{ml}$ on a rotary evaporator $\left(40^{\circ} \mathrm{C}, 50 \mathrm{kPa}\right)$, transferred with methanol into a small vial, reduced to $200 \mu \mathrm{l}$ with a stream of $\mathrm{N}_{2}, 100 \mu \mathrm{g}$ of 3-methoxybenzoic acid added to serve as internal standard and the mixture evaporated to dryness with a stream of $\mathrm{N}_{2}$. To obtain

Table 1. Nitrogen characteristics and total phenol content of the Ah horizons of paired abandoned cropland/native range sites across southern Alberta.

\begin{tabular}{|c|c|c|c|c|c|c|c|c|c|c|c|c|}
\hline & \multirow{2}{*}{\multicolumn{5}{|c|}{$\begin{array}{l}\text { Manyberries } \\
\text { Abandoned }(n=4)\end{array}$}} & \multirow{3}{*}{$\begin{array}{l}\text { Regres- } \\
\text { sion }^{4}\end{array}$} & \multicolumn{2}{|c|}{ Bow Island } & \multicolumn{2}{|c|}{ Fort Macleod } & \multicolumn{2}{|c|}{ Stavely } \\
\hline & & & & & & & \multirow{2}{*}{$\begin{array}{l}\text { Native } \\
(n=4)\end{array}$} & \multirow{2}{*}{$\begin{array}{l}\text { Aband. } \\
(n=4) \\
1922\end{array}$} & \multirow{2}{*}{$\begin{array}{l}\text { Native } \\
(n=8)\end{array}$} & \multirow{2}{*}{$\begin{array}{l}\text { Aband. } \\
(n=8) \\
1884\end{array}$} & \multirow{2}{*}{$\begin{array}{l}\text { Native } \\
(n=4)\end{array}$} & \multirow{2}{*}{$\begin{array}{l}\text { Aband. } \\
(n=4) \\
1916\end{array}$} \\
\hline & $\begin{array}{l}\text { Native } \\
(n=16)\end{array}$ & 1925 & 1927 & 1950 & 1975 & & & & & & & \\
\hline 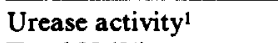 & 237 & 236 & $212^{* *}$ & $198^{* *}$ & $87^{* *}$ & LQ & 248 & $203^{* *}$ & 270 & $222 * *$ & 296 & $176^{* *}$ \\
\hline Total N (\%) & 0.150 & $0.136^{*}$ & $0.135^{*}$ & $0.119^{* *}$ & $0.104^{* *}$ & $\mathrm{~L}$ & 0.160 & 0.131 ** & $\quad 0.430$ & $0.358 * *$ & 0.908 & $0.354^{* *}$ \\
\hline Mineralizable $\mathbf{N}$ & & & & & & & & & & & & \\
\hline $\begin{array}{r}(\mu \mathrm{g} / \mathrm{g} \text { of soill })^{2} \\
\text { Chemical }\end{array}$ & 10.2 & 9.5 & 8.2 & $7.5^{*}$ & $6.5^{* *}$ & $\mathbf{L}$ & 10.6 & 9.3 & 33.0 & $23.2^{* *}$ & 47.3 & $22.0^{* *}$ \\
\hline $\begin{array}{r}\text { ( } \mu \mathrm{g} / \mathrm{g} \text { of soil) } \\
\text { Hydrolyzable } \mathrm{N} \\
(\% \text { of total } \mathrm{N})\end{array}$ & 55.1 & 54.7 & $53.2^{* *}$ & $48.3 * *$ & $34.2^{* *}$ & $\mathbf{L Q}$ & 54.7 & $46.9 * *$ & 165.8 & $112.8 * *$ & 238.2 & $188.6^{* *}$ \\
\hline Total & 79 & 79 & 80 & 83 & $87^{*}$ & $\mathbf{L}$ & 80 & 81 & 75 & 76 & 76 & 78 \\
\hline Amino acid & 35 & 36 & $38 * *$ & $45^{* *}$ & $52 * *$ & $\mathbf{L}$ & 31 & $35^{*}$ & 28 & $33 * *$ & 22 & 37 \\
\hline Amino sugar & 7 & 8 & 8 & 11 & $15^{* *}$ & $\mathbf{L}$ & 12 & 12 & 13 & 14 & 13 & 16 \\
\hline Ammonium & 12 & 13 & 13 & $17^{*}$ & $18^{*}$ & & 11 & 12 & 15 & 16 & 7 & $14^{*}$ \\
\hline Total identified & 54 & $57 *$ & $59 *$ & $73^{* * *}$ & $85^{* *}$ & $\mathbf{L}$ & 54 & $59 * *$ & 56 & $62 * *$ & 42 & $67^{*}$ \\
\hline Exchangeable $N(\mu \mathrm{g} / \mathrm{g}$ & & & & & & & & & & & & \\
\hline $\mathrm{NH}_{4}^{+}-\mathrm{N}$ & 6.2 & 6.3 & 6.1 & $5.4^{*}$ & $3.4^{* *}$ & LQ & 6.8 & 6.7 & 8.6 & $8.1^{* *}$ & 9.2 & $6.2 * *$ \\
\hline $\mathrm{NO}_{4}^{-}-\mathrm{N}$ & 3.3 & 3.5 & 3.6 & $6.5^{* *}$ & $7.4^{* *}$ & LQ & 3.3 & 3.5 & 4.6 & 5.3 & 4.5 & 4.7 \\
\hline Phenols (mg/kg) & 287 & 285 & 281 & 293 & $387^{* *}$ & LQ & 397 & $358^{*}$ & 1104 & $839^{* *}$ & 2006 & $1619^{*}$ \\
\hline
\end{tabular}

*,**Significantly different from corresponding native range values at 0.05 and 0.01 levels of probability, respectively.

$1 \mathrm{NH}^{+}-\mathrm{N}$ released, $\mu \mathrm{g} / \mathrm{g}$ of dry soil per 2 hours.

${ }^{2}$ Change of $\left(\mathrm{NH}_{4}^{+}+\mathrm{NO} \overline{3}\right)-\mathrm{N}$ from two successive incubations of 1 and 2 week periods.

${ }^{3} \mathrm{NH}_{4}^{+}-\mathrm{N}$ released on autoclaving.

'Linear $(\mathrm{L})$ and quadratic $(\mathrm{Q})$ regressions significant at $P \leq 0.05$. 
silylation (Jalal and Read 1983, Pierce Chemical Company 1985), the residue was dissolved in $100 \mu \mathrm{l}$ pyridine and $100 \mu \mathrm{N}, \mathrm{O}$ bis(trimethylsilyl)trifluoroacetamide (BSTFA). To ensure complete derivatization, the sample mixture was heated at $80^{\circ} \mathrm{C}$ in the closed vial for $10 \mathrm{~min}$.

The acid-insoluble organic matter was mixed with $100 \mathrm{ml}$ methylene chloride for $5 \mathrm{~min}$ and decanted into a separatory funnel. The methylene chloride plus 2 subsequent $50-\mathrm{ml}$ methylene chloride washings were transferred to a wide-mouth Erlenmeyer flask. Following the addition of $5 \mathrm{~g}$ of anhydrous $\mathrm{MgSO}_{4}$ for drying the methylene chloride extract, the mixture was stirred for $5 \mathrm{~min}$ and filtered (Whatman \#54). The filtrate was reduced to $2 \mathrm{ml}$ on a rotary evaporator $\left(40^{\circ} \mathrm{C}, 60 \mathrm{kPa}\right)$, transferred with methylene chloride into a small vial, $80 \mu \mathrm{g}$ of tricosanoic acid added to serve as internal standard, and the mixture evaporated to dryness with a stream of nitrogen. Esterification was achieved (Pierce Chemical Company 1985) with the addition of $0.5 \mathrm{ml}$ of a mixture of $N, \mathrm{~N}$ dimethylformamide-dimethyl acetal (9:1). To ensure complete solution and reaction, the sample mixture was heated at $60^{\circ} \mathrm{C}$ in the closed vial for $10 \mathrm{~min}$.

Initial analyses were carried out with a Hewlett Packard GC $5840 \mathrm{~A}$, using a $12-\mathrm{m}$ long capillary column wall-coated with crosslinked methyl silicone for the aliphatic carboxylic acid methyl esters and a 30-m long capillary column wall-coated with $5 \%$ diphenyl-95\% dimethyl polysiloxane (DB-5) for the dicarboxylic acids and phenols. The qualitative analyses were carried out with a Hewlett Packard GC-MS 5985B. Identifications were based on the search of the GC-MS data system and, where possible, authentic samples.

It is recognized that chemical changes occurring within and on the soil are undoubtedly affected by a host of environmental changes that vary with years. Ideally, the most accurate assessment of such changes could be made from repeated analyses of samples taken periodically from well-replicated field plot tests over many years. Although replication and application of current statistical analyses to newly established field plot experiments is common and undeniably desirable and useful, valid information and data can still be gained from early established, unreplicated field experiments, including drill of abandoned crop studies, by virtue of their antiquity (Ridley and Hedlin 1968, Dormaar and Pittmann 1980, Dormaar 1983, Dormaar and Smoliak 1985). Time has exerted a type of replication on the drill of the abandoned cropland study described here.

For each abandoned cropland vs. native range pair, analyses of variance were carried out on the nitrogen characteristics and total phenol data. Since the tests were not replicated, the sampling error was used to test the treatment effects. For the Manyberries area, regression analyses were carried out to relate the observed soil characteristics to the number of years since cropland was abandoned. Since the within-field estimate of variation was not appropriate for testing whether the regressions were significant, the estimate between field variation obtained from the native range samples was used for significance tests. Even though there was loss of statistical elegance by combining the organic acid and phenol extracts, the qualitative trends supply valuable information.

\section{Results}

Regression analyses of soil characteristics against number of years since cropland was abandoned were interpreted to mean that, except for hydrolysable ammonium $\mathrm{N}$, the response to years was linear with the variables urease activity, chemical index, $\mathrm{NH}_{4}^{+}-\mathrm{N}$, $\mathrm{NO}_{4}^{-}-\mathrm{N}$, and phenols possibly having a curvilinear response (Table 1).

The soil data of the 4 native ranges sites at Manyberries were statistically similar, and thus they were averaged (Table 1). The 2 abandoned croplands and 2 native range fields of the Fort Macleod site were statistically similar.

For many variables there were no differences between soil samples from native range and its adjacent field abandoned in 1925 at Manyberries. In the fields abandoned more recently at Manyberries, the difference increased and became more significant as the years since abandonment decreased. Conversely, the data from the 1884 field from Fort Macleod and the 1916 field from Stavely were generally significantly different from those from the adjacent native range. The data from the 1922 field from Bow Island fell generally in between these extremes.

Some measured parameters were lower in the abandoned croplands while others were higher compared with the native range

Table 2. Organic acids and phenols (ng/g of soil) identified in the $\mathrm{Na}_{4} \mathrm{P}_{2} \mathrm{O}_{7}$-soluble, $\mathrm{H}_{2} \mathrm{SO}_{4}$-insoluble fraction from the Ah horizons of paired abandoned cropland/native range sites across southern Alberta.

\begin{tabular}{|c|c|c|c|c|c|c|c|c|c|c|c|c|}
\hline & \multicolumn{5}{|c|}{ Manyberries } & \multicolumn{2}{|c|}{ Bow Island } & \multicolumn{3}{|c|}{ Fort Macleod } & \multicolumn{2}{|c|}{ Stavely } \\
\hline & \multirow[b]{2}{*}{ Native } & \multicolumn{4}{|c|}{ Abandoned } & \multirow[b]{2}{*}{ Native } & \multirow{2}{*}{$\begin{array}{l}\text { Abandoned } \\
1922\end{array}$} & \multirow[b]{2}{*}{ Native } & \multicolumn{2}{|c|}{ Abandoned } & \multirow[b]{2}{*}{ Native } & \multirow{2}{*}{$\begin{array}{c}\text { Abandoned } \\
1916\end{array}$} \\
\hline & & 1925 & 1927 & 1950 & 1975 & & & & $1884 a$ & $1884 b$ & & \\
\hline Benzoic acid & 598 & 590 & 547 & 423 & 266 & 614 & 550 & 212 & 186 & 191 & 129 & 119 \\
\hline Succinic acid & 372 & 376 & 375 & 383 & 731 & 381 & 385 & 1450 & 1620 & 1610 & 2720 & 2840 \\
\hline Fumaric acid & 58 & 64 & 62 & 117 & 124 & 62 & 63 & 99 & 101 & 104 & 125 & 136 \\
\hline Nonanoic acid & 632 & 591 & 574 & 490 & 104 & 646 & 621 & 132 & 112 & 116 & 72 & 61 \\
\hline$?$ & 187 & 188 & 188 & 197 & 207 & 190 & 194 & 29 & 39 & 38 & 21 & 28 \\
\hline$?$ & 138 & 144 & 140 & 157 & 196 & 142 & 144 & 16 & 21 & 20 & 11 & 14 \\
\hline Phenyllactic acid & 181 & 175 & 177 & 123 & 107 & 175 & 170 & 394 & 292 & 287 & 436 & 381 \\
\hline Pimelic acid & 136 & 136 & 134 & 133 & 123 & 134 & 130 & 126 & 113 & 116 & 110 & 107 \\
\hline 4-(OH) benzoic acid & 416 & 417 & 434 & 497 & 700 & 421 & 435 & 371 & 446 & 453 & 362 & 485 \\
\hline \multicolumn{13}{|l|}{ 3-(OH) Phenyl } \\
\hline propionic acid & 99 & 106 & 110 & 396 & 413 & 104 & 110 & 29 & 38 & 36 & 29 & 41 \\
\hline Vanillic acid & 230 & 236 & 248 & 256 & 281 & 225 & 338 & 113 & 144 & 148 & 96 & 124 \\
\hline \multirow{2}{*}{\multicolumn{13}{|c|}{$\begin{array}{l}\text { 3,4-(diOH) benzoic } \\
\text { acid }\end{array}$}} \\
\hline & 81 & 74 & 65 & 61 & 47 & 94 & 89 & 30 & 12 & 16 & 12 & 11 \\
\hline Sebacic acid & 64 & 62 & 105 & 120 & 122 & 69 & 74 & 56 & 41 & 39 & 12 & 30 \\
\hline & 61 & 67 & 69 & 91 & 108 & 68 & 74 & 122 & 161 & 164 & 129 & 148 \\
\hline \multirow{3}{*}{$\begin{array}{l}12-(\mathrm{OH}) \text { dodecanoic } \\
\text { acid } \\
\text { Total } \mu \mathrm{g} / \mathrm{g} \text { soil }\end{array}$} & & & & & & & & & & & & \\
\hline & 67 & 67 & 71 & 72 & 82 & 68 & 73 & 24 & 22 & 22 & 16 & 11 \\
\hline & 3.5 & 3.5 & 3.6 & 4.3 & 4.6 & 3.6 & 3.6 & 4.2 & 4.4 & 4.4 & 5.4 & 5.7 \\
\hline
\end{tabular}


Table 3. Trimethylsilylated aliphatic carboxylic acids ( $\mu_{\mathrm{g}} / \mathrm{z}$ of soil) identifled in the $\mathrm{Na}_{4} \mathrm{P}_{2} \mathrm{O}_{7}$-soluble, $\mathrm{H}_{2} \mathrm{SO}_{4}$-insoluble fraction from the $\mathrm{Ah}$ horizons of paried abandoned cropland/native range sites across southern Alberta.

\begin{tabular}{|c|c|c|c|c|c|c|c|c|c|c|c|c|c|c|c|c|c|c|c|}
\hline Carbon no. & $12: 0$ & $14: 0$ & $16: 1 C$ & $16: 0$ & $17: 0$ & 18:1C & $18: 0$ & 19:0 & $20: 0$ & $21: 0$ & $22: 0$ & $23: 0$ & $24: 0$ & $25: 0$ & $26: 0$ & $28: 0$ & $29: 0$ & $30: 0$ & Total \\
\hline $\begin{array}{l}\text { Manyberries } \\
\text { Native } \\
\text { Abandoned: }\end{array}$ & 16 & 12 & 17 & 32 & 3 & 9 & 17 & 17 & 6 & 42 & 11 & & 7 & 5 & 2 & 2 & 12 & 1 & 211 \\
\hline $\begin{array}{l}1925 \\
1927 \\
1950 \\
1975\end{array}$ & $\begin{array}{r}15 \\
13 \\
9 \\
3\end{array}$ & $\begin{array}{r}11 \\
11 \\
9 \\
8\end{array}$ & $\begin{array}{l}19 \\
20 \\
29 \\
32\end{array}$ & $\begin{array}{l}34 \\
34 \\
46 \\
93\end{array}$ & $\begin{array}{l}3 \\
4 \\
5 \\
7\end{array}$ & $\begin{array}{l}11 \\
11 \\
20 \\
25\end{array}$ & $\begin{array}{l}18 \\
19 \\
55 \\
98\end{array}$ & $\begin{array}{r}16 \\
16 \\
8 \\
3\end{array}$ & $\begin{array}{l}5 \\
5 \\
4 \\
3\end{array}$ & $\begin{array}{r}40 \\
39 \\
11 \\
1\end{array}$ & $\begin{array}{r}10 \\
10 \\
2 \\
-\end{array}$ & $\begin{array}{l}\infty \\
\rightarrow \\
7 \\
7\end{array}$ & $\begin{array}{r}8 \\
8 \\
10 \\
13\end{array}$ & $\begin{array}{r}6 \\
8 \\
10 \\
11\end{array}$ & $\begin{array}{l}3 \\
3 \\
4 \\
5\end{array}$ & $\begin{array}{l}1 \\
1 \\
-\end{array}$ & $\begin{array}{l}13 \\
13 \\
14 \\
15\end{array}$ & $\begin{array}{l}1 \\
1 \\
2 \\
3\end{array}$ & $\begin{array}{l}214 \\
216 \\
238 \\
317\end{array}$ \\
\hline $\begin{array}{l}\text { Bow Island } \\
\text { Native } \\
\text { Abandoned: } \\
1922\end{array}$ & 9 & 12 & 16 & 34 & 3 & 11 & 20 & 17 & 5 & 40 & 10 & $\begin{array}{l}\overrightarrow{0} \\
>\end{array}$ & 6 & 6 & 2 & 2 & 14 & 1 & 208 \\
\hline $\begin{array}{l}\text { Fort Macleod } \\
\text { Native } \\
\text { Abandoned: }\end{array}$ & 5 & 54 & 20 & 265 & 2 & 62 & 98 & 4 & 3 & - & - & & 17 & - & - & 20 & 62 & 12 & 624 \\
\hline $\begin{array}{l}1884 a \\
1884 b\end{array}$ & $\begin{array}{l}2 \\
2\end{array}$ & $\begin{array}{l}18 \\
17\end{array}$ & $\begin{array}{l}30 \\
31\end{array}$ & $\begin{array}{l}151 \\
149\end{array}$ & $\begin{array}{l}1 \\
2\end{array}$ & $\begin{array}{l}27 \\
25\end{array}$ & $\begin{array}{l}34 \\
36\end{array}$ & $\begin{array}{l}2 \\
2\end{array}$ & $\begin{array}{l}2 \\
2\end{array}$ & - & $\overline{-}$ & & $\begin{array}{l}27 \\
24\end{array}$ & - & - & $\begin{array}{l}9 \\
9\end{array}$ & $\begin{array}{l}19 \\
22\end{array}$ & $\begin{array}{l}11 \\
11\end{array}$ & $\begin{array}{l}331 \\
329\end{array}$ \\
\hline $\begin{array}{l}\text { Stavely } \\
\text { Native } \\
\text { Abandoned: } \\
1916\end{array}$ & $\begin{array}{l}6 \\
2\end{array}$ & $\begin{array}{l}74 \\
32\end{array}$ & $\begin{array}{l}21 \\
36\end{array}$ & $\begin{array}{l}283 \\
148\end{array}$ & $\begin{array}{l}2 \\
1\end{array}$ & $\begin{array}{l}69 \\
25\end{array}$ & $\begin{array}{r}114 \\
27\end{array}$ & $\begin{array}{l}6 \\
4\end{array}$ & $\begin{array}{l}4 \\
3\end{array}$ & - & - & & $\begin{array}{l}16 \\
30\end{array}$ & - & - & $\begin{array}{r}19 \\
6\end{array}$ & $\begin{array}{l}66 \\
23\end{array}$ & $\begin{array}{l}11 \\
10\end{array}$ & $\begin{array}{l}691 \\
347\end{array}$ \\
\hline
\end{tabular}

soils. The most pronounced contrast was with the exchangeable $\mathbf{N}$ : $\mathrm{NH}_{4}^{+}-\mathrm{N}$ increased with time of recovery whereas $\mathrm{NH}_{3}^{+}-\mathrm{N}$ decreased towards equilibrium (Table 1). Percent identifiable $\mathrm{N}$ of hydrolyzable $\mathrm{N}$ decreased with time of succession. This indicates a change in the quality and complexity of the soil $\mathrm{N}$ as soil $\mathrm{N}$ changed into a non-hydrolyzable, more stable form over time.

Autoclavable- $\mathrm{N}$, as an index of chemical $\mathrm{N}$ availability, and potentially mineralizable- $\mathrm{N}$, as an index of biological availability, were highest in the native range soils (Table 1). The urease activities also followed the same pattern from recently abandoned cropland to native range. Hence, urease activity and the chemical index, which was simpler and more rapid than the biological approach to $\mathbf{N}$ availability, may be more desirable methods for establishing different pools within overall N. Total phenols (Table 1) decreased with time in the Manyberries soils and increased in the other soils.

By using gas chromatography many compounds were shown to exist in the various extracts. Concentrations of these compounds ranged from 11 to $2,840 \mathrm{ng} / \mathrm{g}$ of soil. Succinic, pimelic, suberic, azelaic, and sebacic acids are all saturated dicarboxylic acids. Fumaric is an unsaturated dibasic acid. The sums of these identified organic acids and phenols overall increased from the Brown to the Black Chernozemic soils even though this did not always hold for individual compounds. This total was generally greater in abandoned cropland soils than in the adjacent native range soils, confirming a more complex type of organic matter in these latter soils. However, the 1975, 1950, 1927, and 1925 abandoned cropland soils sequence vs. the native range soil comparison at Manyberries illustrates the difficulty in interpreting the results of the individual compounds. Overall, benzoic, succinic, nonanoic, 4$(\mathrm{OH})$ benzoic, and vanillic acids were the most important acids identified.

Quantitatively, the soils contained more organic acids in the $\mathrm{Na}_{4} \mathrm{P}_{2} \mathrm{O}_{7}$-soluble, $\mathrm{H}_{2} \mathrm{SO}_{4}$-insoluble fraction than in the $\mathrm{H}_{2} \mathrm{SO}_{4}$ soluble fraction of the organic matter (Table 3 vs. Table 2). Although there were fewer major identifiable aliphatic carboxylic acids in the Black than in the Brown Chernozemic soils, the Black Chernozemic soils nevertheless had larger total values (Table 3). Another major difference between the Brown and Black Chernozemic soils was the quantitative increase of aliphatic carboxylic acids during transformation in the Black and decrease in the
Brown Chernozemic soils. Aliphatic carboxylic acids with $\mathrm{C}$ number 12:0, 17:0, 19:0, 20.0, 21:0, 22:0, 25:0, 25:0, and 26:0 were quantitatively more prevalent in the Brown than in the Black Chernozemic soils. Aliphatic carboxylic acids with $C$ number 16:0, 18:1C, 18:0, and 29:0 decreased during transformation in the Brown but they increased in the Black Chernozemic soils.

\section{Discussion}

The pairs of native range vs. abandoned cropland could not be replicated by year because similarly treated nearby abandoned fields were not available. The Fort Macleod site, with duplicate fields, was a fortunate coincidence. Since the soil data among the 4 native range sites at Manyberries and among the 2 native range sites at Fort Macleod demonstrated good agreement, the data from the abandoned cropland fields were felt, therefore, to be representative of their position in time.

Vreeken (1975) noted that for the development of a specific soil in a given soil landscape, it is necessary to identify 2 aspects of time. First, there is the duration of soil development within a given set of soil-forming factors. Secondly, there is the historical context within which pedologic and geomorphic processes were and are taking place. The present study deals with a sequence of soils that began transforming because of a changing set of soil-forming factors at different moments in the past and are still approaching the state of soil existing under the adjacent native range. Such chronosequences can be used for inferences on pathways of soil organic matter transformations and rates of soil development if it can be assumed, through the principle of uniformitarianism, that soil history repeats itself throughout time regardless of the moment of incipience. Not only have the soils under discussion developed under essentially constant macro-environmental conditions, the history of the abandoned fields prior to abandonment will essentially have affected only the rate and not the pathway of recovery.

One would expect that the length of time land was in cultivation and the cultural treatments imposed would influence the chemical composition and, therefore, the time for recovery. This aspect could not be examined with the present study because the time since abandonment and years of cultivation were confounded. However, the most drastic changes in the chemical composition of soils would occur in the first year of cultivation (McGill et al. 1981). This effect may have influenced the recovery trends observed with 
the Manyberries soils which were cultivated for more than 10 years, except for the soil abandoned in 1975 which had been cultivated for only 1 year. The effects of longer cultivation might be to produce greater contrasts than were presently found and result in more trends, among the chemical constituents studied, that are non-linear.

The data measured the net effects of disturbance, caused by cultivation and erosion, and recovery through the formation of well-humidified organic matter from various types of vegetation. Although the type of vegetation can affect the quantity and quality of soil organic matter (Neal 1969, Rice 1984), the present study only addressed the soil chemical properties as found at a given moment regardless of how they got there. Nevertheless, valuable information on the effects of time of soil chemical transformations may be obtained.

Urease is involved in the chemical transformation of $\mathrm{N}$ in the soil and is primarily produced by microbial and fungal organisms. It was very low in the Manyberries 1975 field, whereas its activity had fully returned in the 1925 field. Conversely, the urease activity of the Black Chernozemic soils at Fort Macleod and Stavely had not recovered fully at the time of this study. Since this gradient in urease activity occurred regardless of the hydrothermal conditions, the increase is likely to be universal, at least under grassland conditions.

Even though hydrolyzable $\mathbf{N}$ as percent of total $\mathbf{N}$ was near equilibrium, except for the very recently abandoned Manyberries 1975 field, the percent $N$ of hydrolyzable $N$ identified always decreased with time of recovery. Soil $\mathbf{N}$ has, therefore, been incorporated into a much more stable type of soil organic matter.

The increase in $\mathrm{NH}_{4}^{+}-\mathrm{N}$ and decrease in $\mathrm{NH}_{3}^{-}-\mathrm{N}$ with time (Table 1) supports the theory that climax species inhibit nitrification (Rice 1984). There is growing evidence that many plant species can use $\mathrm{NH}_{4}^{+}-\mathrm{N}$ as effectively as or more so than $\mathrm{NO}_{3}^{-}-\mathrm{N}$ in climax situations (Rice 1984). This inverse relationship between the amounts of $\mathrm{NO}_{3}^{-}-\mathrm{N}$ and $\mathrm{NH}_{4}^{+}-\mathrm{N}$, i.e., the amount of $\mathrm{NO}_{3}^{-}-\mathrm{N}$ decreases from a high while $\mathrm{NH}_{4}^{+}-\mathrm{N}$ increases from a low in the first successional stage to a low or high value, respectively, in the climax, substantiates not only our earlier findings (Dormaar and Smoliak 1985) but also those of Rice (1984) and Tilman (1986) even though the present results cover 2 separate soil zones. Rice (1984) established that counts of nitrifiers decreased towards the climax stage and hypothesized that to conserve $\mathrm{N}$ the nitrifiers were inhibited under the climax vegetation, thus preventing the oxidation of $\mathrm{NH}_{4}^{+}-\mathrm{N}$ to $\mathrm{NO}_{3}^{+}-\mathrm{N}$. The excess $\mathrm{NH}_{4}^{+}-\mathrm{N}$ is absorbed onto the exchange complex of the soil, thereby becoming less susceptible to leaching.

Soil organic matter is a mixture of many low- and highmolecular weight aliphatic and aromatic compounds and complexes. Extensive suites of compounds can thus be obtained from the soil as evidenced by the present results (Tables 2 and 3 ). Aliphatic carboxylic acids are major components of many organisms and will, therefore, be important contributors to extractable soil organic matter. They are also considered to be one of the possible causes of inhibition of germination and shoot growth leading to reduced productivity (Rice 1984). However, many of the aliphatic carboxylic acids are also chemically stable and persist for long periods of pedological and geological time. Although fingerprint patterns have been discussed for Chernozemic soils (Dormaar 1982), from the current results it seems logical to concentrate future research on the behavior of only some of the major aliphatic carboxylic and other acids in terms of recovery of abandoned cropland. These may include benzoic, succinic, nonanoic, 4-(OH) benzoic, and vanillic acids.

Phenolic compounds exist in the soil and have been studied for their possible role in the solubilization and transport of metal ions during podzolization (Vance et al. 1985) and allelopathic effects (Rice 1984). Although less downward transport occurs in grass- and than in forested soils, phenolic compounds may play an important role in stabilizing metal ions, thereby affecting mineral nutrition, during recovery of abandoned cropland (Dao 1987). The increased phenol levels in the more recently abandoned soils (Table 1) are consistent with inhibited growth in the presence of specific invader species (Rice 1984).

Soil temperature and moisture help control the effect and duration of the biological responses in and on the soil (Pauli 1967). Black Chernozemic organic matter is more stable and, thus, less available for decomposition than Brown Chernozemic organic matter (Dormaar 1975). Up to $39 \%$ of the organic matter of the Brown Chernozemic soils was still in an undecomposed form, compared with $5 \%$ in the Black Chernozemic soils (Dormaar 1977). Volkovintser (1969) noted that drought reduced biological decomposition and thus led to large amounts of dead roots in soils. Further, the organic matter of the Black Chernozemic soils was also much more resistant to decomposition by derivative thermogravimetry than was that of the Brown Chernozemic soils (Lutwick and Dormaar 1976). That is, the intensity of the humification process gradually decreased with increasing soil aridity, making it easier for abandoned cropland to reach that organic matter quality level. Anderson et al. (1974) further noted that organic matter of dry soils was made up of partially decomposed residues and simple, relatively low molecular weight humic materials, with minimal condensation of aromatic structures and readily mineralized nutrient components.

\section{Conclusions}

Results from the study indicate that it will be easier for abandoned cropland on Brown Chernozemic soils to reach the organic matter quality of undisturbed soils than for abandoned Black Chernozemic soils. In order to form the type of organic matter in Black Chernozemic soils that is more stable than that in Brown Chernozemic soils, recovery of abandoned cropland through natural succession and under moderate grazing may take 75 years in the latter and at least 150 years in the former.

\section{Literature Cited}

Anderson, D.W., D.B. Russell, R.J. St. Arnaud, and E.A. Paul. 1974. A comparison of humic fractions of Chernozemic and Luvisolic soils by elemental analyses, UV and ESR spectroscopy. Can. J. Soil Sci. $54: 447-456$.

Association of Official Agricultural Chemists. 1965. Official methods of analysis. 10th ed. Washington, D.C.

Dao, Thanh H. 1987. Sorption and mineralization of plant phenolic acids in soil. p. 358-370. In: George R. Waller (ed.) Allelochemicals: Role in agriculture and forestry. Amer. Chem. Soc., Washington, D.C.

Dormagr, J.F. 1975. Susceptibility of organic matter of Chernozemic Ah horizons to biological decomposition. Can. J. Soil Sci. 55:473-480.

Dormaar, J.F. 1977. La fraction humine dans les horizons Ah de Chernozems modaux et lessivés. Sci. Sol 1977:69-80.

Dormaar, J.F. 1982. Aliphatic carboxylic acids in Chernozemic soils. Can. J. Soil Sci. 62:487-494.

Dormaar, J.F. 1983. Chemical properties of soil and water-stable aggregates after sixty-seven years of cropping to spring wheat. Plant Soil 75:51-61.

Dormaar, J.F., and U.J. Pittman. 1980. Decomposition of organic residues as affected by various dryland spring wheat-fallow rotations. Can. J. Soil Sci. 60:97-106.

Dormaar, J.F., and S. Smoliak. 1985. Recovery of vegetative cover and soil organic matter during revegetation of abandoned farmland in a semiarid climate. J. Range Manage. 38:487-491.

Dormaar, J.F., A. Johnston, and S. Smoliak. 1977. Seasonal variation in chemical characteristics of soil organic matter of grazed and ungrazed Mixed Prairie and Fescue grassland. J. Range Manage. 30:195-198.

Environment Canada. 1982. Canadian climate normals. Vol. 3. Precipitation. Downsview, Ont.

Jalal, M.A.F., and D.J. Read. 1983. The organic acid composition of Calluna heathland soil with special reference to phyto- and fungitoxicity. I. Isolation and identification of organic acids. Plant Soil 70:257-272. 
Keeney, D.R. 1982. Nitrogen-Availability indices. In: A.L. Page (ed.) Methods of soil analysis. Part 2. Chemical and microbiological properties. Agron. 9:711-733. Amer. Soc. Agron., Madison, Wis.

Keeney, D.C., and D.W. Nelson. 1982. Nitrogen-Inorganic forms. In: A.L. Page (ed.) Methods of soil analysis. Part 2. Chemical and microbiological properties. Agron. 9:643-698. Amer. Soc. Agron., Madison, Wis.

Lutwick, L.E., and J.F. Dormar. 1976. Relationships bet ween the nature of soil organic matter and root lignins of grasses in a zonal sequence of Chernozemic soils. Can. J. Soil Sci. 56:363-371.

MacKay, D.C., and J.M. Carefoot. 1981. Control of water content in laboratory determination of mineralizable nitrogen in soils. Soil Sci. Soc. Amer. J. 45:444-446.

McGill, W.B., C.A. Campbell, J.F. Dormaar, E.A. Paul, and D.W. Anderson. 1981. Soil organic matter losses. Proc. 18th Annu. Alta. Soil Sci. Workshop, Edmonton, pp. 72-133.

Morits, H. 1980. Total phenolic content in the pyrophosphate extracts of two peat soil profiles. Can. J. Soil Sci. 60:291-297.

Neal, J.L., Jr. 1969. Inhibition of nitrifying bacteria by grass and forb root extracts. Can. J. Microbiol. 15:633-635.

Pauli, F.W. 1967. Soil fertility: A biodynamical approach. Adam Hilger Ltd., London.
Pierce Chemical Company. 1985. Pierce $1985-86$ handbook and general catalogue. Rockford, III.

Rice, E.L. 1984. Allelopathy. 2nd ed. Academic Press, Inc., New York.

Ridley, A.O., and R.A. Hedlin. 1968. Soil organic matter and crop yields as influenced by the frequency of summerfallowing. Can. J. Soil Sci. 48:315-322.

Stevenson, F.J. 1982. Nitrogen-Organic forms. In: A.L. Page (ed.) Methods of soil analysis. Part 2. Chemical and microbiological properties. Agron. 9:625-641. Amer. Soc. Agron., Madison, Wis.

Tabatabai, M.A., and J.M. Bremner. 1972. Assay of urease activity in soils. Soil Biol. Biochem. 4:479-487.

Tilman, D. 1986. Nitrogen-limited growth in plants from different successional stages. Ecology 67:555-563.

Vance, G.F., S.A. Boyd, and D.L. Mokma. 1985. Extraction of phenolic compounds from a Spodosol profile: An evaluation of three extractants. Soil Sci. 140:412-420.

Volkovinster, V.I. 1969. Soil formation in the steppe basins of southern Siberia. Sov. Soil Sci. 1969:383-391.

Vreeken, W.J. 1975. Principal kinds of chronosequences and their significance in soil history. J. Soil Sci. 26:378-394. 